\section{O Boletim Médico: prescrição dos tisiólogos para a cura da cidade de São José dos Campos (1930-1935)}

\section{The Boletim Médico: the tuberculosis specialists' prescription for curing the city of São José dos Campos (1930-1935)}

Valéria Zanetti

Professora de história e pesquisadora da Universidade do Vale do Paraíba (Univap); membro do Núcleo de Pesquisa Pró-Memória/São José dos Campos. vzanetti@univap.br

Maria Aparecida Papali

Professora de história e pesquisadora da Univap São José dos Campos - SP; membro do Núcleo de Pesquisa Pró-Memória/São José dos Campos. papali@univap.br

Maria José Acedo del Olmo

Professora de história e pesquisadora; membro do Núcleo de Pesquisa Pró-Memória/São José dos Campos. mj.acedo@yahoo.com.br

\section{Paula V. CarnevaleVianna}

Professora de saúde coletiva e pesquisadora em planejamento urbano e regional da Univap. paulavianna@univap.br

Universidade do Vale do Paraíba Av. Shishima Hifumi, 2911 12244-240 - São José dos Campos - SP - Brasil

Recebido para publicação em fevereiro de 2009. Aprovado para publicação em abril de 2010.
ZANETTI, Valéria et al. O Boletim Médico: prescrição dos tisiólogos para a cura da cidade de São José dos Campos (1930-1935). História, Ciência, Saúde Manguinhos, Rio de Janeiro, v.17, n.3, jul.-set. 2010, p.719-737.

Resumo

Analisa a transformação da cidade de São José dos Campos em Estância Climatérica para o tratamento da tuberculose pulmonar, condição oficialmente instituída em 1935. Por meio de análise do periódico editado pel os tisiologistas da cidade, Boletim Médico, e de fontes correlatas, são analisadas a motivação e as estratégias desse grupo profissional na conversão da pacata cidade de São José dos Campos em centro de referência para a cura da tuberculose. A investigação dos argumentos técnicos que ampararam esse projeto reforça a constatação de que a condição de estância era, simultaneamente, ameaça à população da cidade e motriz da economia local, baseada, até a década de 1950, quase que exclusivamente na exploração da doença.

Palavras-chave: tuberculose; Boletim Médico; sanitarismo; São José dos Campos; Brasil.

\section{Abstract}

Thearticle explores thetransformation of the city of São José dos Campos, which in 1935 received the official designation of "health resort" for the treatment of pulmonary tuberculosis. Research of Boletim Médico (a periodical published by the city's tuberculosis specialists) and of other, related sources grounds this analysis of both the motives and the strategies of this professional group when the quiet little town of São José dos Campos was transformed into a major center for tuberculosis cures. This examination of the technical arguments in support of the project reinforces the idea that thecity's status as a health resort was both a threat to city residents and also a driving force behind the local economy, based almost exclusively on exploiting the disease through the 1950s.

Keywords: tuberculosis; Boletim Médico; public health; São José dos Campos; Brazil. 
Em determinado momento, os doentes passaram a dar a tônica na vida de São José dos Campos. De sua debilidade vinha a proficiência financeira da cidade... Houve um momento em que todos acreditavam que São J osé nunca mais deixaria de ser uma estância climática... (Bondesan, São José em quatro tempos).

São José dos Campos, anônima até a primeira década do século $X X$, começou, a partir daí, a ser reconhecida pelos resultados satisfatórios na cura da tuberculose. Vivendo sob o regime de pequenas e médias fazendas de café no passado escravista, a economia do município permaneceu, até 1930, constantemente em crise. A pequena produção de café não conferia à São José imperial um lugar de destaque junto às forças políticas nacionais, como foi o caso das vizinhas Taubaté, Jacareí, Lorena e Bananal, bem representadas pelos influentes barões de café (Milliet, 1946, p.41).

Os recursos provenientes da produção cafeeira foram escassos durante as primeiras décadas do século XX (Ricci, 2006, p.27). Em 1908 o vice-prefeito em exercício comunicou à Câmara a exiguidade da arrecadação e exigiu "providências a respeito", o que resultou em cobrança judicial dos contribuintes "relapsos" (Actas..., 25 fev.1908). Em 1918 a arrecadação diminuiu consideravelmente devido à suspensão da cobrança do imposto sobre cafeeiros durante os exercícios de 1918 a 1920 (Actas..., 15 jun. 1918). A persistência do deficit nos períodos subsequentes exigiu da Câmara novas medidas, que incluíram o arrendamento de terrenos para captação de receitas (Actas..., 15 maio 1929, 20 mar. 1929; Parecer 26/1927, 15 ago. 1927)

O município buscava apoio estadual e federal para equilibrar o orçamento. No entanto, os parcos recursos arrecadados não eram suficientes para saldar a dívida que se avolumava. A situação se agravou com o colapso da produção de café. A retração do mercado e queda da produção, sujeita a constantes invasões de pragas e permanentes secas, levou à falência muitos produtores da região. ${ }^{1}$ Essencialmente agrícola, a cidade de São José assistia ao êxodo de sua população para o promissor Oeste paulista.

Esse cenário desolador da perspectiva demográfica e econômica foi modificado pela 'migração tuberculosa', ocorrida nas três primeiras décadas do século XX. O considerável fluxo de pessoas que buscava a cidade para tratamento acabou por gerar nova receita e significativo aumento populacional. O município cresceu de forma acentuada: a população triplicou na virada do século XX, e o índice de crescimento demográfico anual manteve-se alto até 1935 (Tabela 1). A mesma ten dência éobservável na comparação de dados censitários entre 1900 e 1950 (Tabela 2). O que teria impulsionado esse crescimento nas décadas que precederam o grande boom industrial na década de 1970, na região?

O aumento populacional do município de São José dos Campos deveu-se à chegada de pessoas acometidas pelo bacilo de Koch. Foram tão constantes as levas de portadores da doença que, em 1905, um artigo do periódico local O Caixeiro exigia do poder público medidas higiênicas para evitar a disseminação da temida peste branca, sob o risco de "dois grandes prejuízos: o desenvolvimento dessa moléstia (tuberculose) e o descrédito da cidade quanto a sua salubridade". O articulista desse jornal assistiu ao cumprimento da 'profecia'. 
A ideia da construção de um sanatório na cidade, em 1920, por empreendedores paulistas aumentou significativamente o número de doentes, e várias foram as tentativas de criar, forçosamente, uma imagem de cidade salubre.

Em 1938, conforme censo encomendado pelo então prefeito sanitário José Longo, 1.154 doentes, correspondentes a $10 \%$ da população urbana, distribuíam-se nos cinco sanatórios da cidade e nas inúmeras pensões, repúblicas e residências que viviam do acolhimento de doentes (São J osé dos Campos, 1938). O crescimento demográfico, em plena crise econômica, acentuou os problemas urbanos, sobretudo a pobreza. Articulistas do periódico local Correio Joseense noticiavam constantemente os problemas cotidianos sofridos pela e na cidade, buscando formas de resolvêlos, particularmente nas seções Pela Cidade e $O$ que Devemos Fazer: Em Defesa da Cidade. A todo momento, an unciavam a intensa invasão dos portadores da temível peste branca.

Tabela 1: População do Vale do Paraíba paulista: números absolutos e crescimento demográfico (1854-1935)

\begin{tabular}{lccccc}
\hline Municípios & $\mathbf{1 8 5 4}$ & $\mathbf{1 8 8 6}$ & $\mathbf{1 9 2 0}$ & $\mathbf{1 9 3 5}$ & $\begin{array}{c}\text { Crescimento } \\
\text { demográfico(\% a.a.) }\end{array}$ \\
\hline Areias & 11.663 & 25.661 & 22.147 & 23.635 & 0,63 \\
\hline Bananal & - & 17.654 & 11.507 & 12.932 & $-0,75$ \\
\hline Guaratinguetá & 13.714 & 25.632 & 43.101 & 38.838 & 0,80 \\
\hline Jacareí & 9.861 & 16.565 & 25.363 & 31.300 & 0,85 \\
\hline S.J.Campos & 6.935 & 17.906 & 30.681 & 31.606 & 0,96 \\
\hline Taubaté & 22.307 & 40.624 & 85.433 & 68.040 & 0,83 \\
\hline Outros munic. & 41.249 & 87.522 & 131.361 & 136.114 & 0,86 \\
\hline Total & $\mathbf{1 3 7 . 9 4 1}$ & $\mathbf{3 1 4 . 6 7 5}$ & $\mathbf{4 7 7 . 0 7 1}$ & $\mathbf{4 6 7 . 2 2 1}$ & $\mathbf{0 , 8 7}$ \\
\hline
\end{tabular}

Fonte: Construído a partir de Milliet, 1946, p.37.

Tabela 2: Evolução decenal da população nos municípios do Vale do Paraíba paulista (1900-1950)

\begin{tabular}{lrrrrr}
\hline Municípios & $\mathbf{1 9 0 0}$ & $\mathbf{1 9 2 0}$ & $\mathbf{1 9 4 0}$ & $\mathbf{1 9 5 0}$ & $\begin{array}{c}\text { Crescimento } \\
\text { demográfico (\% a.a.) }\end{array}$ \\
\hline Caçapava & 12.267 & 18.099 & 16.352 & 19.301 & 0,73 \\
\hline Cruzeiro & 11.075 & 12.676 & 16.466 & 19.918 & 0,89 \\
\hline Guaratinguetá & 38.263 & 42.101 & 29.345 & 36.657 & $-0,09$ \\
\hline Jacareí & 15.309 & 18.135 & 23.669 & 27.561 & 0,89 \\
\hline Lorena & 12.895 & 15.645 & 15.961 & 24.569 & 0,95 \\
\hline Pindamonhangaba & 21.871 & 26.493 & 22.995 & 28.901 & 0,49 \\
\hline S.J.Campos & 18.122 & 30.681 & 36.279 & 44.804 & 1,19 \\
\hline Taubaté & 36.723 & 45.445 & 40.970 & 52.997 & 0,61 \\
\hline Outras cidades & 173.149 & 159.729 & 197.009 & 198.028 & 0,25 \\
\hline Total & $\mathbf{3 3 9 . 6 7 4}$ & $\mathbf{3 6 9 . 0 0 4}$ & $\mathbf{3 9 9 . 0 4 6}$ & $\mathbf{4 5 2 . 7 3 6}$ & $\mathbf{0 , 5 0}$ \\
\hline
\end{tabular}

Fonte: IBGE: Dados populacionais. Censo 1900-1950. 
No entanto, dentro das poucas possibilidades para fazer frente à retração econômica da década de 1920, a doença representou, pela força da população que comportava, a cura necessária à cidade (Vianna, 2007; Almeida, 2008). Já no final do século XIX, São José dos Campos era conhecida nacional mente como "a cidade que curava". A força desse discurso chegou com intensidade nas reuniões da Câmara Municipal no início do século XX. M eios de viabilizar e intensificar a vinda dos doentes eram discutidos, gerando um verdadeiro arsenal de propagandas para atraí-los em quantidade.

Os almanaques publicados em 1905 e em 1922 são evidências contundentes desse esforço (Câmara, 1905; Monteiro, 1922). Essas publicações eram recheadas de anúncios de farmácias; de pensões; de clínicas pulmonares; de compostos que prometiam acabar milagrosamente com o bacilo de Koch; de anúncios de médicos especialistas na doença que dizimava sem piedade a indefesa população; do aclamado clima adequado para tratamento dos doentes do peito; da localização aprazível da cidade, intermediada pela Serra da Mantiqueira; da "adequada infraestrutura", própria da dinâmica de uma cidade moderna etc. $\mathrm{O}$ almanaque anunciava, em suas páginas, a representação de uma cidade ideal para o tratamento do grande mal - cidade que ainda não existia.

Em 1914, a compra de um terreno pela Prefeitura para alojar o sanatório Vicentina Aranha, inaugurado em 1924, foi o primeiro grande passo para a oficialização do ideário municipal. Pertencente à irmandade da Santa Casa de Misericórdia da capital, o prédio foi construído com recursos da Câmara Municipal de São Paulo, do governo federal e do "alto comércio" paulista, além de fundos beneficentes angariados pela elite paulistana (Vianna, 2004). Apoiada pelos tisiólogos e pelo médico-prefeito Rodolfo S. Mascarenhas, a oficialização da estância de tratamento da tuberculose seria, a partir daí, uma questão de tempo.

Havia interesse em fazer de São José uma estância climatérica e hidromineral? Por que era importante para a cidade essa con dição? Não se temia a convivência com os tuberculosos forasteiros? Os joseenses acolheram de bom grado a ideia do polo sanatorial? Teria a cidade reais condições de tratar os doentes e, ao mesmo tempo, proteger a população local contra a temida contaminação? Qual foi o papel dos médicos na construção desse projeto?

Nas décadas de 1920 e 1930, a elite intelectual brasileira - médicos, engenheiros e professores - influenciou de maneira significativa o processo de urbanização. Milton Santos (1996) chegou a conceituar as cidades do início do século XX como "cidades de notáveis". Conferindo-Ihes o ideário de modernidade 'civilizatória', as ideias e ações procuravam enterrar o 'atraso colonial' e 'implantar um éthos capitalista'. Uma das estratégias para isso foi a reformulação do espaço urbano (Hershmann, Pereira, 1994, p.26-29).

A análise do Boletim Médico, material pouco conhecido pelos pesquisadores do tema, traz respostas elucidativas às questões formuladas, revelando o olhar e as ações dos médicos tisiologistas que atuaram sobre o cenário urbano e sanitário joseense. Pouco se sabe das condições de produção desse periódico, uma vez que, nele, elas não são mencionadas, tampouco se encontraram informações sobre ele em outras fontes da época. Sabe-se apenas que o Boletim era publicação bimestral, que circulou entre 1932 e 1936 e que foi mantido "com a colaboração de todos os especialistas da estação climatérica" (Boletim Médico, 1933, capa). Muitos desses colaboradores estavam ligados a atividades comerciais relacionadas 
ao tratamento da tuberculose e exerciam cargos de administração em sanatórios, clínicas e farmácias.

O período curto de circulação do Boletim pode ser explicado pelo propósito que parece têlo gerado: consolidar, divulgar e legitimar um saber especializado que propagaria a condição de São José dos Campos como estância climatérica e hidromineral. O periódico é importante fonte histórica, esclarecedora sobre a posição dos diferentes grupos médicos e políticos com relação à pleiteada condição, para a cidade, de centro de tratamento da tuberculose. Serviu de instrumento de propaganda para reforçar os benefícios do clima (Boletim Médico, 1933, p.3), as "excelentes condições sanitárias e higiênicas", bem como propagou a "infraestrutura apropriada para atender, sem receio, os portadores da moléstia" (p.3).

Em tempos de centralização política, quando os municípios eram administrados por interventores, a publicação do Boletim ocupou o vazio documental deixado pela ausência de fontes diretamente ligadas à administração pública, durante a paralisação dos órgãos do poder legislativo nos estados e municípios, decretada por Getúlio Vargas, nas décadas de 1930 e $1940 .^{2}$

Há que considerar também, como importante base documental, os jornais joseenses que circulavam na época3. Porém, o Boletim possui características que o qualificam como fonte única sobre as condições médicas e sanitárias em São Paulo, e particularmente em São José dos Campos, nas três primeiras décadas do século passado. O periódico deve ser anal isado no contexto intelectual que lhe foi contemporâneo, em quenovos conhecimentos técnicos e científicos abriam o caminho para o progresso e a modernidade.

$\mathrm{Na}$ área médica, os conhecimentos provenientes de pesquisas empíricas eram divulgados em congressos, conferências e publicações especializadas; revistas, livros e manuais difundiam o conhecimento médico-sanitário no país (Almeida, 2000), estabelecen do comunicação entre a comunidade científica e a sociedade (Castro Santos, Ferreira, 1999). Os textos ganharam uma escrita condizente com esse novo campo de saber e poder, compartilhando, por meio de uma linguagem direta e técnica, a pragmática visão científica que se estenderia a outras formas de manifestação intelectual (Sá, 2006, p.100-103).

O Boletim, nesse contexto, serviu a um propósito técnico e social ao retratar não só as preocupações médicas, como também questões imperativas do setor político local sobre as polêmicas discussões do momento. A leitura atenta dessa fonte deixa entrever os interesses em jogo. Adicionalmente, as propagandas comerciais indicam os inúmeros setores envolvidos no lucrativo negócio da doença: farmácias, estabelecimentos comerciais (açougues, casas bancárias, armazéns, lavanderias), hotéis, clínicas de tratamento, pensões, imobiliárias, casas de construção, entre outros.

\section{A estância climática e hidromineral: a tuberculose como negócio}

Em 1930, antecedendo a publicação do Boletim, o estudante da Faculdade de Medicina e Cirurgia de São Paulo João Amaral realizou um estudo das condições sanitárias do município, como exigência da cadeira de Higiene. Influenciado pela Fundação Rockefeller, o Instituto de Higiene aliava o ensino científico da higiene à prática, preparando os alunos para atuar como sanitaristas (Vasconcellos, 1995, p.30-31). Para tanto, atividades labora- 
Valéria Zanetti et al.

toriais eram incentivadas, bem como excursões e inspeções sanitárias na cidade eno interior. Identificada a "condição de saúde pública da comunidade", o aluno deveria produzir "cartas sanitárias municipais", real izar inspeções sanitárias, ou mesmo planejar a distribuição de postos e dispensários (p.35).

Conhecimentos sobre saúde e cidade eram articulados por meio de observação direta e registro fotográfico, conforme os preceitos do sanitarismo então vigente. Em 1930 o relatório sanitário sobre São José, apresentado pelo aspirante a médico, segue essas orientações, numa avaliação crítica da cidade e de seus equipamentos sanitários. O sanatório Vicentina Aranha, inaugurado em 1924, recebeu amplos elogios; não era à toa que se havia tornado referência nacional no tratamento da doença. As condições sanitárias do prédio e a administração foram consideradas satisfatórias pelo estudante de medicina:

O sanatório admite doentes de ambos os sexos etem duas classes-a dos pensionistase a dos gratuitos.

O edifício central éreservado para os pensionistas. Conta três pavimentos: o 3o édestinado à residência do pessoal do sanatório; o 2ํำ destinado às mulheres, estando localizada no centro deste a capela (provisória); no 1o pavimento estão instaladoso consultório, a sala depequena cirurgia, curativos, injecções, etc., o gabinete deraios- $X$, com câmara escura, gabinete de otorrinolaringologia, o laboratório, a farmácia, a gerência ea sala dosmédicos, ala do vestíbulo.

Esta seção comporta 46 pensionistas, divididos em três categorias, conformeos aposentos que ocupam - A, B, C: os preços das suas pen sões são, respectivamente, de 1:200\$000, $900 \$ 000$ e $600 \$ 000$ (mensal mente), estan do já compreen didos neste preço os serviços médicos.

Há quatro pavilhões para doentes pobres, sendo dois grandes e dois pequenos com capaci dade - os gran des para 20, e os pequenos para 10 doentes. Cada sexo ocupa um pavilhão grandeeum pequeno.

Comporta, pois, o sanatório pouco mais de uma centena de doentes.

A administração interna [é] confiada às irmãs deS. José (Amaral, 1930, p.136).

Enquanto as condições higiênicas e sanitárias do Vicentina Aranha foram elogiadas, não faltaram críticas ao funcionamento das pensões que alojavam tísicos. Perplexo com o elevado número de hospedarias na cidade em 1930, Amaral ressaltava que o número de tuberculosos na cidade seria muito provavelmente subestimado, uma vez que a atividade consistia em forma vantajosa de obtenção de recursos. As irregularidades observadas pelo estudante no aspecto sanitário da cidade levaram-no a concluir que o poder público, inoperante, compactuava com aquele "grave estado de coisas":

São José dos Campos, sob o ponto de vista sanitário, não pode ser equi parado a uma cidade comum. Estância Climatérica, ondeas condiçõesordinárias deum centro populoso secomplicam com as suas condições peculiares de hospedeira detuberculose em busca de alívio, devia ter um aparel hamento sanitário em proporção com as suas necessidades.

Cidade com uma população de 30.000 habitantes, em cujo seio uma massa de mais de meio milheiro detuberculosos se concentra em várias dezenas de casas de pensão, não dispõe, para todo o serviço de higiene urbana, de mais do que- um inspector, um guarda edois ou tres 'mata-mosquitos'... Osquais, como sedemasiadosfossem, têm de multiplicarse ainda para soccorrer à vigi lância de vários outros municípios e distritos. 
É deconvir queé pouco... émuito pouco mesmo....

Essa escassez de pessoal éuma atenuante para certas irregularidades que seobservam no tocante à vila sanitária da cidade, e mais uma vez vem comprovar a nossa afirmação de que São J osé dos Campos - inegavel mente fadado a um grande futuro, dada sua condição de Canaã dos tuberculosos - éuma cidade não apenas descurada, como abandonada pel os poderes públicos (Amaral, 1930, p.129; grifos nossos).

Bastante consistente, o relatório invalidava as determinações que fariam do município uma estância de cura, apesar de a cidade viver praticamente do negócio da 'saúde'. O posto sanitário local, por exemplo, exigia que a abertura das pensões fosse precedida de uma licença, com ficha do proprietário e vistoria do prédio, mas, conforme nos relata Amaral, algumas não se adequavam às exigências sanitárias:

Encontramos a pensão de um sírio, cujo nome não ficamos sabendo; até há pouco tempo possuía um armazém de secos emolhados em frente ao Mercado M unicipal; como as coisas não Ihe corressem bem, resolveu mudar de negócio; disseram-Ihe que casa de pensão "dá mais"; al i estava poiscom a sua pensão aberta- uma casa comum deresidência, sem a menor obra de adaptação - já com um ou dois patrícios doentes abol etados em quartinhos sujos, atulhados de malas e móveisordinários.

Nem sequer se preocupara com requerer licença. Para que tanta formalidade?

...

Seria muito racional que, para se abrir uma casa de hospedagem para tuberculosos, além de se exigir o preenchimento de certas condições quanto ao prédio, se exigissem também, do pretendente, condições deidoneidademoral: não é, por certo, qual quer vendedor de secose molhados - cujos con hecimentos secifram em saber quantos mil réis ganhou ou perdeu no fim de cada dia - que está à altura de compreender o seu papel e a sua responsabilidadecomo chefe de um estabelecimento dessa natureza.

E o que observamosem certas pensões (sobretudo deitalianosesírios) nosleva a concluir que tais casas apresentam um perigo real, não só para os hóspedes, doentes, como para a população sã da cidade: vimos em várias delas doentes escarran do no chão, com a maior sem-cerimônia (é verdade que no quintal, mas sempre ao al cance das moscas), a casa ain da desarrumada e suja, transformada em foco de moscas, em horas nas quais já há muito devia estar composta e limpa: crianças da família do proprietário na mais absoluta comunidadecom tuberculosos (jogando com el es dama, víspora etc.), inscientes do risco que estão correndo.

Tudo isso por falta dos mais elementares conhecimentos de higiene individual esocial por parte dos respon sáveis (Amaral, 1930, p.161-162).

Além do extenso rol de estabelecimentos sem condições ideais de funcionamento, 23 pensões estavam regulares, na opinião de Amaral (1930), todas concentradas no Centro da cidade. Como a fonte de riqueza estava assentada na doença, casas populares insalubres e sem condições de al ojar, muito menos tratar, os portadores do bacilo tornavam-se moradas detuberculosos, representando ameaça à saúde pública. A economia do município, ancorada fortemente na doença, paradoxalmente deixava transparecer a fragilidade das condições estruturais da cidade como estância, objetivo último da aspiração médica local.

Contaminação e prevenção se tornavam as engrenagens do arriscado empreendimento. O prefeito sanitário (etisiologista), doutor Rui Dória, em 1930, argumentava: “não precisamos 
Valéria Zanetti et al.

de máquinas. Isso é para Taubaté e Jacareí. Precisamos é de doentes.... Essa é a nossa indústria" (citado em Bondesan, 1967, p.31). Uma indústria que se ben eficiava, inclusive, do monopólio da morte. O projeto de lei de 18 de março de 1930 concedia exclusividade do serviço funerário no município à Santa Casa de Misericórdia de São José dos Campos. 0 instrumento legal garantiria

\begin{abstract}
à Santa Casa o monopólio sobre o comércio da morte. Somente a mesma poderia fabricar caixões e artigos funerários even dêlos, estabelecer o serviço de transporte funerário. A concessionária podia contratar o serviço funerário de terceiros, mas durante a concessão (período de 30 anos), a Câmara não concederia licen ça para a fabricação e comércio de artigos funerários ecaixões mortuários, bem como o transportefún ebre(Almeida, 2008, p.59-60).
\end{abstract}

A vocação sanatorial de São José dos Campos criou um comércio em torno da doença, da cura e da morte. Em 1924, ano da inauguração do sanatório Vicentina Aranha, a Câmara Municipal autorizou o prefeito, pela lei n. 142, a ampliar a área do cemitério "aproveitando os terrenos da praça fronteira a necrópole, promovendo a construção dos respectivos muros de fecho, e dividindo o terreno no acrescido com essa incorporação em quadras para sepulturas de primeira, segunda e terceira classe" (Correio Joseense, 27 jan. 1924, p.4; grifos nossos).

A lei municipal 145, de abril de 1924 isentava do imposto de indústria e profissão, pelo prazo de dez anos, os estabelecimentos funerários que fossem fundados na cidade (Correio Joseense, 27 abr. 1924). Além da expansão do cemitério, foram instaladas na cidade fábricas de mosaicos e produtos cerâmicos, assim como de túmulos de mármore (Actas..., 15 set. 1928). As precárias condições higiênicas e sanitárias de algumas pensões certamente ampliaram a acumulação de riquezas baseadas nos negócios da morte.

Se São José dos Campos não dispunha de infraestrutura sanitária para ser oficialmente considerada centro de referência e tratamento da tuberculose, alguns 'méritos' poderiam alçar a cidade a tal condição (Amaral, 1930, p.160). Além das propagadas condições climáticas naturais, da migração de doentes e da presença do sanatório, Amaral considerou a "abundante" rede de farmácias, "singularidade que desperta logo a atenção do visitante" (p.153) e um precioso capital: oito médicos, sendo cinco tisiólogos. Ao menos dois, Nélson D'Avila, "uma das personalidades mais benquistas e influentes do município", eRuy Dória, "adversário político de Nélson d'Avila", clinicavam em aparelhados consultórios (p.152-153).

Evidentemente, a constatação dos bons ares da cidade não a transformava natural mente em estância. Seriam necessários argumentos com forte poder de persuasão para vencer o temor dos residentes na cidade. Para que a condição de estância fosse consensualmente almejada por todos e conferida pelo Estado era necessário um trabalho em duas frentes: dissimular as reais condições urbanas, que poderiam inviabilizar o pleito feito ao Estado, e refutar o estigma e o medo de contágio e morte associados à doença. O discurso técnico tratou desses aspectos, como se depreende da análise dos artigos publicados no Boletim. 


\section{A estância idealizada: ação dos tisiologistas entre a tuberculose e a cidade}

O Boletim M édico surgiu em um momento em que as forças políticas locais impingiam à cidade a condição de polo sanatorial e, simultaneamente, buscavam formas de preservar a cidade da contaminação em massa. Nesse empreendimento, os médicos tinham função destacada, criando condições para que a invasão de tuberculosos fosse controlada e não representasse perigo à comunidade.

O periódico circulou com edições bimensais durante quatro anos. Não há informação acerca da sua tiragem. De início o tabloide era distribuído gratuitamente no estado de São Paulo, sul de Minas Gerais e Rio de Janeiro. A partir de setembro de 1935, passou a ser cobrada assinatura anual, iniciativa que coincidiu com a data de oficialização da estância e mudança do redator do Boletim, com a substituição do doutor João B. de Souza Soares pelo doutor Ruy Dória.

Os fascículos eram compostos de um editorial, cerca de dois a quatro artigos médicos e espaços reservados para divulgação comercial. Além dos tisiólogos de São José, artigos de autoria de tisiologistas ilustres como Clemente Ferreira e Hélio Fraga eram transcritos e amplamente debatidos. Clemente Ferreira teve participação importante em um editorial sobre colapsoterapia e sua carta foi publicada na íntegra no número de janeiro de 1936. Os artigos técnicos incluíam revisões, apresentação de casos raros e estudos experimentais que abrangiam novas técnicas diagnósticas e laboratoriais e terapias intervencionistas.

O Boletim era amparado e subvencionado pelo poder público por seu "incontestável valor para o futuro de nossa pouco conhecida São José dos Campos" (Actas..., 18 mar. 1930) ${ }^{4}$, futuro este imputado à força médica para torná-la importante estância climatérica. Era objetivo do Boletim "difundir o conhecimento dos problemas da tuberculose, fazendo conhecida sua profilaxia e seus problemas de higiene entre os leigos e sua terapêutica entre os profissionaes" (Boletim Médico, maio-jun.1934, p.16).

Por meio do Boletim, os doentes das mais longínquas regiões do Brasil tomaram conhecimento "da boa direção", "da disciplina rígida" e da "localização segura das instalações" que, na cidade, acolhiam os tuberculosos. A publicação também informava os vantajosos valores de estada e custo de vida. Em resposta à repercussão do Boletim, a seção Indicador do Boletim Médico passou a constar, a partir do terceiro número, com endereços de sanatórios, hotéis, pensões, médicos efarmácias, entre outros estabel ecimentos. Serviu ainda como veículo de propaganda das múltiplas vantagens que a cidade oferecia aos tísicos, "com suas obras de assistência social, com aspectos de sua topografia encantadora, seus fartos recursos profissionais e comerciais, etc." (Boletim Médico, maio 1933, p.1).

Do ponto de vista técnico, o Boletim foi um instrumento utilizado pelos médicos para divulgação de casos interessantes vividos na prática clínica, bem como de resultados de suas experiências e pesquisas. A linguagem técnica reforçava a autoridade científica dos envolvidos e dava legitimidade ao pleito. Os editoriais, por sua vez, mesclavam os argumentos técnicos e administrativos à retórica emotiva, comunicando "o carinho que nesta terra se dispensa aos problemas da luta contra o desolador flagelo da raça humana" (Boletim Médico, maio 1933, p.5). Artigos assinados pelos médicos José Rosemberg, Ivan 
de Souza Lopes e João Batista de Souza Soares defendiam o estabelecimento de sanatórios populares e a necessidade de uma séria política sanitária e higienista (Boletim Médico, maio 1933, jul. 1933, jul. 1934). Nas páginas do informativo transparecem as diferentes vertentes políticas ligadas, inclusive, à expansão urbana da cidade. O posicionamento profissional acerca da Prefeitura Sanitária, consensualmente pleiteada pelos médicos e pelo diretor do Departamento de Administração Municipal desde 1933, foi tema em diversos números, abordado em geral no Editorial. O informe foi utilizado pelos profissionais para esclarecer a população a respeito das normas legais de funcionamento da estância. Os especialistas deixavam claro à população que a prefeitura sanitária não acarretaria novos impostos nem traria "despesas incompatíveis com o angustioso momento econômico. Também não é seu fim, como muitos pensam, entregar a cidade aos tuberculosos" (Boletim Médico, jun.1933, p.2).

Nota-se o desconhecimento acerca da institucionalização da estância. O temor da iniciativa no que concerne às esferas econômica e social fica evidente. Para acalmar os ânimos daqueles que poderiam obstaculizar o al mejado destino de cidade sanatorial, os médicos trataram logo deexplicar: "a presença de um engenheiro especial izado em questões sanitárias, com a assistência médica indispensável, será a garantia de uma orientação perfeita dos serviços municipaes ... Os serviços de higiene e assistência pública serão também ampliados eaperfeiçoados" (Boletim M édico, jun. 1933, p.2). Assegurava-se, aos amedrontados cidadãos joseenses, que a cidade não seria entregue aos tuberculosos.

Os serviços públicos eficientes, tão almejados pela municipalidade, como rede de esgotos e água encanada, na visão dos médicos só viriam com a Prefeitura Sanitária. Os tisiólogos ressal tavam: "dentro desse regimen administrativo, o município verá aplicados, em seu benefício, os recursos municipais, accrescidos dos que, no regimen atual, o Estado arrecada, em São José dos Campos" (p.2). A condição de estância permitiria à administração contar com um montante de oitocentos contos anuais, deduzidos apenas os vencimentos dos funcionários das várias repartições da Prefeitura Sanitária, que seriam transformados em benefícios que, segundo os médicos, "só podem recusar os interesseiros e os ignorantes" (p.2).

A primazia da técnica era reiterada pelos médicos cientistas; ousados na defesa da condição sanatorial para a cidade, temiam que o prefeito sanitário se aproveitasse da posição para criar um esquema de interesses pessoais e políticos: "é preciso, entretanto, reconhecer quão justificado é o temor que muitos têm de que a Prefeitura Sanitária seja transformada, pelo filhotismo e pela falsa noção que muita gente tem da caridade, em uma espécie de retiro para os que, afetados em sua saúde, quiserem repartir os seus padecimentos com o interesse público. E é também o que tememos..." (Boletim Médico, jun. 1933, p.2).

Por ser o segmento médico diretamente responsável pela promoção da cidade a estância "hospedeira da tuberculose" (Boletim Médico, out. 1933, p.2), compreende-se sua preocupação com a política da administração sanitária no município. Pretendiam os médicos evitar que atropelos ou interesses políticos do prefeito comprometessem o projeto e os desacreditassem perante a população. Tornava-se, necessário, então, “que, desde logo, sejam incluídos na própria lei de criação de nossa Prefeitura Sanitária, dispositivos que vedem a admissão, em seus serviços, de pessoas que não disponham da capacidade de trabalho suficiente para os respectivos cargos... E é, exactamente, o que é preciso, a todo o transe, 
evitar para que não permaneçam no papel os planos grandiosos que traz em seu bojo a ideia de Prefeitura Sanitária" (Boletim Médico, jun.1933, p.2).

Entre sentimentos de medo e ousadia, e sob o ideário daquele início de século, os especial istas defendiam a ideia de que era possível administrar a doença com uma organização técnica dirigida por médicos e engenheiros sanitários. Acreditavam que a organização sanitária de uma cidade com clima propício para o tratamento da tuberculose requeria autoridades municipais especializadas (Boletim Médico, jul. 1933, p.5). Em crítica feroz à política do então prefeito, o qual al egavam que não condizia com as necessidades do cargo, os médicos manifestavam preocupação com que a doen ça tomasse proporções incontroláveis:

as medidas de proteção e higiene vêm sendo vítimas, em S. Josédos Campos, deinjunções políticas ou deoutras origens, que Ihes destroem toda eficiência. ... Sem uma autoridade técnica, única e indiscutível, emanada de outro ponto que não o meio local, onde a população e os homens públicos que el a cria vivem verdadeiramente à margem desses problemas, desapercebidos do papel médico-social da cidade, como hospedeira da tuberculose de todas as procedên cias, jamais se conseguirá em São J osé dos Campos o centro sanitário que São Paulo já não pode dispen sar (Boletim M édico, out.1933, p.3).

Duvidando da conduta dos administradores locais, os médicos denunciavam que a falta de conhecimentos especializados, imprescindíveis para a direção de um município de necessidades sanitárias particulares como São José dos Campos, trazia constantes embaraços à ação do higienista e do engenheiro sanitário (Boletim Médico, out. 1933, p.2).

À força dos especialistas juntavam-se as de comerciantes e donos de pensões - alguns deles médicos -, sanatórios e alojamentos. O Boletim Médico registrou o árduo trabalho dos médicos, uma vez que as condições naturais e o desinteresse dos investidores no ramo inviabilizavam o empreendimento. Sem grandes trunfos industriais, o jeito foi buscar as potencialidades naturais de São José e enaltecêlas. Utilizando-se da força da persuasão e de alegações técnicas, amparados pelo discurso dos "bons ares", os tisiólogos encontraram um forte argumento para atrair seus clientes.

A vocação da cidade, construída basicamente com a propaganda dos benefícios de seus ares e escorada nos lucros advindos dessa forçosa adjetivação, animava as forças locais, que contavam com apoio de entidades filantrópicas e parceiros da sociedade civil. Simultaneamente criou-se, para atrai r o interesse de industriais, uma comissão especial encarregada de divulgar as vantagens que a cidade oferecia ao ramo - vantagens que também estavam além das suas reais possibilidades, incluindo promessa de favores, por parte da Câmara, aos investidores.

O combate ao bacilo seria realizado por parceria dos especialistas, que defendiam, com base no conhecimento técnico de então, a aeração como condição básica para o tratamento. No Boletim, o entusiasmo pelo dote climático da cidade foi sistematicamente reforçado, o que contribuiu para revigorar os anseios públicos. No primeiro número do periódico, os especialistas enunciavam: "há muito, vínhamos sentindo a necessidade de propagar de modo mais amplo o nosso entusiasmo pelo clima maravilhoso de São José dos Campos, cujas virtudes operam à nossa vista tantos e reais prodígios" (Boletim Médico, maio 1933, p.1). 
Valéria Zanetti et al.

Embora diversos periódicos locais enaltecessem as condições climáticas da cidade, o Boletim conferiu legitimidade científica ao que era 'empiricamente' observado. Em edição de 1925 de 0 Correio Joseense, lê-se:

Embora existam no mundo muitos países com clima bom, poucos são os lugares que se destacam por um clima excepcional como Davosea Ilha da M adeira.

No Estado de São Paulo temos Campos de Jordão e São José dos Campos. Pelo primeiro tem se feito muita propagan da e, embora de grande emerecida fama, não é para todos os doentes, devido a sua altura, por ser muito difícil a viagem e por falta derecursos. De São José dos Campos nunca foi feita propaganda, como entretanto hoje ele está se impondo éo melhor sinal quereal mente possui o que se chama ideal.

Há dezenas de anos chegam aqui pessoas doentes quevoltaram curadas para seus lares, pessoas que eram dadas como casos perdidos pel os seus médicos e que chamaram a atenção para São José. ...

Possui São Josétodos os recursos e os seus médicos dedicadíssimos gozam de real fama para doen ças pulmonares... (Correio Joseense, 18 jun. 1925).

Já no Boletim Médico o tema ganhou outro contorno. Uma reprodução da Conferência de Diógenes Certain, representante do Dispensário Clemente Ferreira, em São Paulo, destacava as diversas características a serem analisadas em relação ao clima: temperatura, umidade, irradiação solar, pressão barométrica, luminosidade, pureza do ar, ventos, latitude/ longitude, altitude, natureza do solo, composição geológica, cursos d'água e florestas (Boletim Médico, ago.1934, p.8-12).

No entanto, a climaterapia passava a ser analisada pela ciência. A medicina pasteuriana, precedendo a descoberta do tratamento medicamentoso da tuberculose, já questionava o papel de clima, repouso e alimentação em medidas terapêuticas. Diógenes afirmava:

A climatologia ea climaterapia têm ain da de sofrer muitas restrições nas suas indicações e resultados. Não estão ainda assentes suas bases eesteé o motivo da desconfiança de uns e das surpresas desagradáveis de outros. Os processos modernos de cura vêm suprindo nos lugares a que fal tam virtudes terapêuticas o deslocamento dos doentes para fora de seus lares ou das ci dades em que exercem suas atividades (Boletim M édico, ago. 1934, p.11).

O clima tornava-se coadjuvante do tratamento. Em São José, no entanto, sobrevivia o discurso hegemônico local. Os tisiologistas rebatiam o contradiscurso do clima favorável da cidade, denunciando "o absurdo de tais doutrinas": "hoje em tisiologia discute-se a questão dos climas e, como reação ao outro extremo que fazia da estação climatérica condição sine qua do tratamento, têm surgido opiniões exageradas que querem negar-lhes todo e qualquer valor" (Boletim Médico, out.1933, p.2; grifos nossos).

A experiência ainda era contraposta à argumentação científica. Nas páginas do Boletim Médico (nov. 1933, p.2), o doutor Soares afirmava: "o que é essencial sob o ponto de vista individual é procurar de preferência um clima realmente experimentado, com longos anos de observação documentada, e não um clima apontado como tal por um ou mais interessados na sua exploração como estância de cura".

Os médicos, na defensiva, embora apoiados na ciência, acautelavam-se na tese de que não era seguro "avaliar qualidade de um clima pela simples inspeção dos dados meteo- 
rológicos. É preciso recorrer à experiência clínica, e daí a vantagem de preferir climas já procurados há muitos anos por grandes quantidades de doentes, com resultados evidentes" (Boletim Médico, maio 1933, p.1). Planejavam, inclusive, um cinturão sanitário-climático que abrangesse diferentes altitudes, com estâncias em Campos, São José e Caraguatatuba (Boletim Médico, out. 1933, p.3).

Os médicos, de diferentes posicionamentos e ideários, deixavam claro que as discussões não eram partidárias: "não se trata ... dos interesses do Partido Republicano Paulista, ou do Partido Socialista e nem dos Voluntários ou dos Democráticos, nem mesmo dos Católicos serem atendidos em suas conveniências partidárias com essa solução. Mas os interesses da saúde publica estarão defendidos e amparados com segurança (Boletim Médico, out. 1933, p.3).

Tecnicamente amparados, os especialistas encaminharam ao Serviço Sanitário do Estado um memorial para a oficialização da cidade como estância (Boletim Médico, out. 1933, p.4). Unindo interesses múltiplos, o perfil da futura cidade se delineava, e em 1933 São José dos Campos alcançava a condição de Estância Climatérica.

Médicos, administradores locais e comerciantes viram na doença do peito a cura da cidade terminal. O mercado da moléstia constituiu importante fonte de renda, permitiu que segmentos se capitalizassem com ele e conferiu à cidade uma via alternativa de desenvolvimento urbano. A evolução do número de habitantes por município, já no início do século XX, revelava uma tendência acelerada de crescimento populacional em São José dos Campos, em comparação regional (Reschilian, 2005, p.5; Tabelas 1 e 2).

A argumentação técnica e politicamente articulada dos médicos com o Estado, divulgada no Boletim M édico, foi atendida, e São José dos Campos, em 1935, promovida a Estância Climatérica; finalmente o tão afamado e polêmico clima da cidade trouxe novos ares para ela. Pouco tempo depois, conquistou-se um novo título: em 16 de dezembro do mesmo ano, a cidade passou a ser também estância hidromineral, para surpresa de muitos. Os médicos de São José dos Campos, atuando em plena cidadelaboratório, ganharam fama e prestígio político. Sua força extravasou consultórios e clínicas, e ganhou espaço nos domínios da administração pública.

Com a tran sformação em estância climatérica, o prefeito do município (prefeito sanitário) passou a ser nomeado pelo estado; a eleição da Câmara por voto popular foi mantida e o município passou a receber verba adicional, através do Fundo para Melhoria das Estâncias (Fumest), para aparel hamento. As receitas, a partir daí, seriam constituídas de impostos e taxas arrecadados no município pela Prefeitura e pelo estado, sendo a renda municipal destinada à manutenção da administração munici pal e a renda estadual, aos serviços públicos, a fim de aprimorar a infraestrutura urbana da estância (Vianna, 2004, p.130-131).

A nova condição deu ânimo aos rendimentos da cidade e equilibrou-se a sua receita. $O$ município, que no final do século XIX mostrava um quadro desolador, conseguiu se recuperar e ganhar fôlego para empreender as mudanças exigidas pelo momento, de considerável crescimento urbano. Não se pode negar que essas conquistas se devem, sobretudo, à atuação dos médicos locais - muitos delesideal istas, convictos das suas pesquisas científicas; outros, muito mais envolvidos com a rentabilidade do negócio. 
A acolhida estadual da reivindicação dos médicos criou um grande impasse: o título de Estância Climatérica e Hidromineral precedeu as condições necessárias para a cidade tornarse um centro de referência em tratamento da tuberculose. São José dos Campos carecia dos meios para tal, inclusive equipamentos urbanos e política específica para o controle da doença. Com o título conquistado pela cidade, os médicos teriam que empreender grandes esforços técnicos e políticos para concretizar o almejado desejo de tratar dos doentes e conter a propagação da tuberculose. Um gran de trunfo para essa conquista, segundo parece, foi a verba adicional que o município passou a contar do Estado.

\section{A estância oficial: a cidade remodelada}

Se a estância climatérica era um engodo, a estância hidromineral era uma verdadeira blasfêmia, na opinião de muitos moradores. ${ }^{5} \mathrm{~A}$ pequena fonte de água "que possibilitou esta conversão ..., além de pequena vazão, era imprópria para o consumo" (Vianna, 2004, p.128).

Ora, a concretização do ideário modernizador, ligado ao caráter higienista e sanitário, exigia 'limpeza' do espaço urbano, sua aeração, adequado abastecimento d'água, instalação de esgoto e ruas cal çadas. O 'líquido precioso', demasiadamente reduzido para uma estância hidromineral, deixava por longos períodos a cidade na mais completa seca. Para assegurar o projeto sanatorial, o problema de abastecimento d'água deveria ser sanado, e este passou a ser o grande desafio dos médicos do peito que lutaram pelo título alcançado.

Em 1933 avaliou-se o inacabado e deficiente serviço de abastecimento, inaugurado ainda em 1909 e que captava as elevadas águas da Boa Vista para o centro da cidade. Sua má qualidade e o alto grau de contaminação, com "a presença de 10.000 colis (bacilos) por 100 centímetros cúbicos, ... a colocou entre as águas de péssima qualidade e há muito deveria ter sido considerada pelas autoridades sanitárias como imprópria para o consumo" (Correio Joseense, ago. 1933, p.6).

Além disso, o sistema, constantemente interrompido por entupimento de canos causado por desabamentos nos morros, não supria a população, que crescia vertiginosamente. Em 1937 a municipalidade, em decorrência da condição de estância climatérica, portanto apoiada pelo governo do estado, pôde reavaliar sua rede de abastecimento. Os médicos reforçaram a condenação das águas, realizada quatro anos antes pela Repartição das Águas e Esgotos. A alternativa de captar as águas do rio Paraíba, tratá-la com cloro, decantá-la e filtrá-la criou animosidade na população, que recusava as águas do rio poluído por esgotos de outras cidades. Criou-se um impasse, pois os órgãos competentes acusavam a população de desenvolver "um fetichismo pelas águas de fontes puríssimas". Na visão dos especialistas, era "um erro abandonar águas próximas de tratamento fácil para buscar, à custa de sacrifícios enormes, águas altas, de cabeceiras, águas de regimes incertos e quase sempre insuficientes só pela esperança vã e sem fundamento de que sejam mais puras que as outras" (Correio Joseense, 6 jun. 1937, p.1).

A concretização da estância repousava agora em outro saber, o da engenharia. Embates opuseram a Prefeitura Sanitária ao Departamento das M unicipalidades, órgão que executava os serviços de abastecimento deágua. Segundo consta, o prefeito sanitário chegou a embargar 
obras porque o técnico daquele Departamento "pretendia construir, justamente no largo da Matriz, uma torre de 26 metros de altura por 8 metros de largura, prejudican do não só aquela bela praça na sua área como na sua estética" (Correio Joseense, 9 jan. 1938, p.2). Os elementos de modernização do espaço, autoritariamente impostos, incomodavam a população joseense.

Os engenheiros, administradores e, posteriormente, arquitetos se uniram aos médicos em sua missão civilizatória, mantendo o autoritarismo técnico e a política centralizadora. Influenciados pela doutrina positivista, adotavam postura intervencionista na vida pessoal e na política de saúde, mesclando ciência e moral. A filosofia vigente da medicina 'curadora' de todos os males, inclusive os sociais, aliava-se à proposta modernizadora de racional ização dos espaços. Os médicos influenciavam a vida urbana e social; eram eles consultados para escolha do melhor local para edificação de estabelecimentos de cura e para ampliar os espaços públicos, defendendo a desapropriação e demolição de moradias que impediam a livre circulação dos ares.

A atuação sobre o espaço urbano, tecnicamente legitimada, foi facilitada pelo desempenho político dos tisiologistas. Entre os 15 médicos que clinicaram na cidade de 1904 a 1950 (12 tisiologistas), nove foram vereadores e seis prefeitos (Silva, 2009, p.49). Em 1930 o médico Ruy Dória passou a integrar a Junta Governamental de São José dos Campos, em substituição ao governo vigentee à Câmara Municipal, extinta até 1936. Dória foi o primeiro interventor da República Nova, nomeado em 1931.

Com a abertura da Câmara, ocorrida após a criação da Estância, o prefeito engenheiro sanitário passou a ser indicado pelo governador e subordinado ao Departamento de Administração Municipal. Médicos voltaram a ocupar a Câmara de Vereadores e, por seguidas vezes, a cadeira de chefe do Executivo, influenciando diretamente nas políticas públicas. Atrelada à proposta de fazer da cidade um centro de tratamento de doenças, a política de mel horamento urbano estava intrinsecamente ligada aos médicos e engenheiros sanitaristas. As ações apregoadas incluíam colocação de guias e apedregulhamento das ruas e praças, ajardinamento e arborização da cidade, serviço de encanamento, regularização do abastecimento de água, iluminação pública por el etricidade e construção de fossas sépticas aneróbicas e rede de esgotos. Elas foram efetivamente aplicadas ao espaço urbano a partir de 1935, acelerando as mudanças iniciadas uma década antes: "A cidade vel ha, um tanto anti-higiênica, está sendo reformada com casas modernas, a água aumentada, a usina de força e luz grandemente melhorada" (Correio Joseense, 18 jun. 1925, p.2). Os melhoramentos concentraram-se na região central da cidade, com a criação da zona sanatorial e a construção do Pavilhão da Higiene (1935).

As mudanças urbanas seguiram céleres. A gestão do engenheiro sanitário Francisco José Longo (1938-1941) marcou a transformação do traçado urbano. A modesta rua São José, na região central, foi ampliada e transformada em avenida. A demolição das casas do lado par da rua abriram a vista para um grande vale, o Banhado, fortalecendo a imagem de estação de cura da tuberculose.

Como a água, por escassez e inviabilidade, não limpava o espaço, a limpeza se deu por outras vias, implementadas de forma autoritária e discriminatória. Os casebres ocupados pela população pobre e considerados insalubres foram destruídos para dar lugar a largas 
avenidas, corredores de circulação e espaços destinados a abastecimento de água e à iluminação.

O aprimoramento da infraestrutura urbana, inicialmente nas zonas central/sanatorial, foi possibilitado pelo incremento de recursos provenientes do crescimento do comércio local, bem como da verba estadual, que aumentou o orçamento municipal em $50 \%$. Os terrenos próximos à área sanatorial, no circuito imobiliário que constituiria a área nobre da cidade, valorizaram-se. A urbanização, precoce da perspectiva regional, antecede a industrialização (Vianna, 2004). São José se destacou, igualmente, em relação à saúde.

O movimento histórico de institucionalização da saúde pública no país deve ser espacialmente diferenciado. $O$ interior do país, vítima do atraso e das endemias, foi gradativamente ocupado pelo aparato burocrático das delegacias de saúde (Hochman, 1998) e suas ações preventivas, medidas educativas e de caráter coletivo. Nas capitais e cidades mercantis, além do controle das doenças endêmicas, a ação higienizadora influenciou a reformulação do espaço urbano, em projetos racionais e estéticos que buscavam modernizar as cidades coloniais. A assistência médica, separada das ações de saúde pública, proporcionaria, por sua vez, condições para o pleno exercício do trabalho (Gadelha, 1982). Em grande parte das cidades brasileiras, os melhoramentos implicavam eliminação de doenças e expulsão de doentes, como forma de reordenação do espaço, principalmente o relacionado a seu perímetro central.

A cidade de São José dos Campos não se ajusta a esse modelo conceitual. Aqui, as mudanças urbanas concretizariam o projeto sanatorial e, simultaneamente, atrairiam o doente, convertido em alternativa à estagnação econômica e social da cidade na virada do século XX. Foi, sobretudo, em razão da existência dos doentes que a cidade se modernizou. O doente em fase sanatorial ocupou o espaço urbano central, que recebeu, graças ao capital oriundo da doença e de seus portadores, uma atenção maior do poder público, viabilizando e sustentando a modernização urbana. A mercantilização da doença retirou de São José dos Campos a condição de cidade morta.

"As largas avenidas, bem calçadas, com parques bem tratados", "a água abundante e purificada", "os esgotos eficientes", "o clima salubre" eram al gumas das expressões dos idealizadores do projeto sanatorial, propagadas pelo Boletim Médico, que potencializavam, para além da realidade, os dotes da cidade.

\section{A estância: avaliação sanitária após uma década de oficialização}

São José não só alojou como promoveu a doença. Na cidade, o aparato institucional do estado, no que tange à saúde pública, foi enredado por interesses econômicos e projetos políticos que consideravam a tuberculose a motriz do desenvolvimento urbano. Formouse um aparato público, ligado ao Estado, dirigido aos doentes em pior situação econômica e orientado para implantação de medidas normativas, e outro privado, ligado a médicos especialistas, sanatórios, circuito econômico, para controle e tratamento da doença.

Uma inspeção do Departamento de Saúde Pública, em 1944, revelava: "São José dos Camposéum foco ativo detuberculose [pois] número considerável de indivíduos adquiriram a doença na cidade" (Flório, 1944, p.58-59). O relatório aponta as dificuldades em garantir 
a segurança dos doentes e da cidade: as condições pecuniárias dos tuberculosos, assim como a falta de habitações na zona sanatorial para acomodar a população forasteira doente compeliam "a população sã a viver em promiscuidade com as pessoas doentes obrigando-os a um contágio permanente" (p.59).

No mesmo relatório destaca-se o crescimento da cidade e dos serviços de saúde. Entre as casas de alvenaria, na região central (algumas em "condições condenáveis", ocupadas por tuberculosos), e de taipa, na região rural, foram identificados um fórum, três agências bancárias, escolas, mercado, igrejas, um cinema, um hotel "de construção moderna" e 25 bares e cafés, a maior parte na zona comercial e al guns na zona sanatorial.

Os serviços de saúde da cidade, em 1944, eram compostos por seis san atórios, um hospital filantrópico - a Santa Casa de Misericórdia, para doentes não contagiosos - e um centro de saúde, todos subsidiados pela prefeitura. Treze médicos cuidavam da população de cerca de 40 mil pessoas. Metade dos recursos do centro de saúde era direcionada aos funcionários da Tecelagem Parahyba, primeira grande indústria da cidade. O relatório ainda ressaltava a "boa capacidade filantrópica" da cidade, concretizada em quatro associações particulares e duas religiosas, consideradas necessárias à "causa da saúde pública".

Um olhar para a cidade em relação ao território estadual, no entanto, revela as possibilidades de mudança do perfil sanatorial. Abririam outros caminhos para o município o investimento público em infraestrutura urbana, possibilitado pela subvenção estadual; os incentivos fiscais; a população, que se ampliava em relação ao vale do Paraíba; a proximidade de São Paulo; a incipiente industrialização (com a primeira indústria química da cidade, em 1945); os avanços da medicina, incluindo o tratamento quimioterápico da tuberculose; e a proximidade com o poder estadual, advinda com a condição de estância.

Notadamente, num primeiro momento a indústria da doença possibilitou que a cidade de São José dos Campos se expandisse economicamente e atingisse expressiva taxa de urbanização. Não temos como negar que a mercantilização da doença do peito pelos médicos, reforçada e legitimada por meio da divulgação do Boletim Médico, acabou se tornando a prescrição quea cidade precisava, mesmo queseus efeitos colateraisse mostrassem por demais arriscados, por ter atingido na mesma medida a saúde pública, a política econômica e o planejamento urbano.

\section{NOTAS}

${ }^{1}$ Essa crise pode ser constatada nos relatórios da Prefeitura publicados no Correio Joseense entre 1920 e 1935, bem como nas atas da Câmara de Vereadores da cidade.

2 Atas da câmara são importantes fontes historiográficas para revelar as discussões acerca da política, projetos e reformas urbanas. Entre 1930 e 1945, no governo de Getulio Vargas, em decorrência da dissolução do Congresso Nacional, todos os órgãos legislativos nos estados e municípios foram paralisados, passando a ser chefiados por interventores estaduais e federais, que, nomeados pelo poder público, centralizavam todas as decisões. As pesquisas históricas que abrangem esse período enfrentam dificuldades, por não poder contar as atas das Câmaras municipais, fonte esclarecedora dos problemas da cidade e das soluções adotadas pelas administrações locais.

${ }^{3}$ O Correio Joseense é o periódico mais antigo da cidade e o mais completo para consulta. Circulou entre 1920 e 1964, com exceção do ano de 1928, quando o diretor do jornal se mudou temporariamente para a cidade de São Paulo. 
Valéria Zanetti et al.

${ }^{4}$ Esta ata registra que os editores do Boletim M édico solicitaram uma subvenção destinada a prover parte do custeio da publicação. Na sessão de 15 de maio do mesmo ano, a Comissão de Finanças e Justiça da Câmara, examinando o pedido, destinou um auxílio de 200 mil réis para o periódico (Actas..., 18 mar. 1930).

${ }^{5}$ Essa ideia pode ser comprovada nas edições do Correio Joseense, de 1935 até 1938.

\section{REFERÊNCIAS}

ACTAS...

Actas da Câmara Municipal de São José dos Campos. Fundo Câmara Municipal de São José dos Campos. (Arquivo Público do Município de São José dos Campos). 1908-1930

ALMEIDA, Marta de.

Combates sanitários e embates científicos: Emílio Ribas e a febre amarela em São Paulo. História, Ciências, Saúde - Manguinhos, Rio de Janeiro, v.6, n.3, p.577-607. Disponível em: http://www.scielo.br/scielo.php?script= sci_arttext\&pid=S0104-597020000 $00 \overline{4} 00005 \&$ lng $=$ pt\& $\mathrm{nrm}=$ iso Acesso em: 22 set. 2009. 2000.

ALMEIDA, Valéria Zanetti.

Cidade e identidade: São José dos Campos, do peito e dos ares. Tese (Doutorado) - Programa de Pós-graduação em História Social, Pontifícia Universidade Católica de São Paulo, São Paulo. 2008.

AMARAL, João Ferraz do.

Inspecção sanitária de São José dos Campos. Universidade de São Paulo, Faculdade de

Medicina. Trabalho apresentado como exigência da cadeira de Higiene.

Documentação da Fase Sanatorial.

(Laboratório de Pesquisa e Documentação Histórica; Instituto de Pesquisa e Desenvolvimento da Universidade do Vale do Paraíba). 1930.

BOLETIM MÉDICO.

São José dos Campos. (Arquivo Público do Município de São José dos Campos). 1933a 1935.

BONDESAN, Altino.

São José em quatro tempos. São José dos Campos: Bentivegna. 1967.

CÂMARA, Sebastião Penna da (Org.). Almanach de São José dos Campos para 1905. Ano 1. Jacarehy: Typographia da Casa Minerva. 1905.

CASTRO SANTOS, Luiz A. de; FERREIRA, Luis Otávio.

Os periódicos médicos e a invenção de uma agenda sanitária para o Brasil (1827-1843). História, Ciências, Saúde - Manguinhos, Rio de Janeiro, v.6, n.2, p.331-351. Disponível em http://www.scielo.br/scielo.php?script= sci_arttext\&pid=S0104-5970199900030 $0006 \&$ lng $=$ pt\&nrm=iso. Acesso em: 18 set 2009. 1999.

\section{CORREIO JOSEENSE.}

São José dos Campos. (Arquivo Público do Município de São José dos Campos). 1920-1950.

FLÓRIO, João.

Relatório de inspeção preliminar do município e estância climatérica de São José dos Campos. São Paulo. Departamento de Saúde Pública do Estado de São Paulo; Divisão de Serviço do Interior. Documentação da Fase Sanatorial. (Laboratório de Pesquisa e Documentação Histórica; Instituto de Pesquisa e Desenvolvimento da Universidade do Vale do Paraíba). 1944.

GADELHA, Paulo. E.V.

Assistência médica no Rio de Janeiro (1920/1937): reformas institucionais e transformação da prática médica. Tese (Mestrado) - Instituto de Medicina Social, Universidade do Estado do Rio de Janeiro, Rio de Janeiro. 1982.

HERSHMANN, Micael M.; PEREIRA, Carlos Alberto Messeder.

O imaginário moderno no Brasil. In: Hershmann, Micael M.; Pereira, Carlos Alberto Messeder (Org). A invenção do Brasil moderno: medicina, educação e engenharia nos anos 20-30. Rio de Janeiro: Rocco. p.9-42. 1994.

HOCHMAN, Gilberto.

A era do saneamento. São Paulo: Hucitec; Anpocs. 1998.

MILLIET, Sérgio.

Roteiro do café. São Paulo: Bipa. 1946.

MONTEIRO, Napoleão (Org.).

Almanach de 1922. São José dos Campos: s.n. 1922.

RESCHILIAN, Paulo Romano.

O Vale do Paraíba no contexto da urbanização brasileira e a questão do planejamento regional. Revista Ciências Humanas, Taubaté, v.11, n.1, p.25-32. 2005.

RICCI, Fábio.

A economia cafeeira e as bases do 
desenvolvimento no Vale do Paraíba paulista. Revista História Econômica \& Economia Regional Aplicada, Taubaté, v.1, n.1, p.1-11. 2006.

SÁ, Dominichi Miranda de.

A ciência como profissão: médicos, bacharéis e cientistas no Brasil (1895-1935). Rio de Janeiro: Editora Fiocruz. (Coleção História e Saúde). 2006.

SANTOS, Milton.

A urbanização brasileira. 3.ed. São Paulo: Hucitec. 1996.

\section{SÃO JOSÉ DOS CAMPOS.}

Prefeitura Municipal de São José dos Campos. Serviço de Estatística Municipal. Anuário estatístico da estância hidromineral e climatérica de São José dos Campos. Apresentado ao Prefeito Sanitário, Engenheiro Francisco José Longo. São José dos Campos: s.n. 1938.

SILVA, Ana Consuelo Alves da.

Dores do corpo e dores da alma: o estigma da tuberculose entre homens e mulheres acometidos. Tese (Doutorado) - Faculdade de Educação, Universidade Estadual de Campinas, Campinas. 2009.

VASCONCELLOS, Maria da Penha C. (Coord.). Memórias da saúde pública: a fotografia como testemunha. São Paulo: Hucitec. 1995.

VIANNA, Paula Viana Carnevale.

Saúde e cidade: uma relação inscrita no espaço e no tempo; a fase sanatorial de São José dos Campos (SP) e sua influência sobre os serviços de saúde da década de 1980. Tese (Doutorado) - Faculdade de Medicina, Universidade de São Paulo, São Paulo. 2004.

VIANNA, Paula Viana Carnevale; ELIAS, Paulo Eduardo.

Cidade sanatorial, cidade industrial: espaço urbano e política de saúde em São José dos Campos, São Paulo, Brasil. Cadernos de Saúde Pública, Rio de Janeiro, v.23, n.6, p.1295-1308. 2007.

\section{uUuUUU}

